\title{
EL PASADO DE UN MITO
}

DARÍO MACOR

Texto publicado originalmente en El Paraninfo, periódico de la UNL. Santa Fe, octubre de 2005.

La noche del 17 de octubre de 1945, cuando Perón saluda desde el balcón de la Casa Rosada a la multitud que lo aclama, se completa un acto cuya importancia en la historia de la Argentina del siglo XX no puede disimularse. Lo que acababa de acontecer resultará decisivo en la resolución de la crisis política que jaqueaba al gobierno militar iniciado en 1943, transformándose rápidamente en el mito fundacional de una nueva fuerza política que marcará desde entonces la dirección y las modalidades del proceso político argentino.

Es difícil encontrar en el proceso histórico un nudo de condensación tan claro como el de ese día. Desde su origen el 17 tiene todos los condimentos que hacen a un mito, y las más diversas lecturas del peronismo se detendrán especialmente en esos momentos iniciales tratando de desentrañar los fragmentos constitutivos de la identidad popular que irrumpía entonces. Luego del triunfo en las elecciones de febrero de 1946 el peronismo gobernante habrá de canonizar una versión del 17 , construyendo un mito fundacional capaz de generar representaciones sociales fuertemente dadoras de identidad.

En la versión peronista lo que caracteriza al 17 es la movilización espontánea de los sectores populares a la Plaza de Mayo. De esta manera, el peronismo pone en un plano invisible a los aparatos sindicales que se habían movilizado para rescatar a Perón y mantener las conquistas logradas en los meses anteriores gracias a su gestión en la Secretaría de Trabajo. Esta operación, le permitía al peronismo emergente ocluir toda la historia del movimiento sindical y sus dirigentes anarquistas, socialistas y comunistas; y, a la vez, jerarquizar un elemento esencial a todo movimiento populista: el vínculo directo entre el líder y la masa; vínculo que no requiere de intermediarios para su concreción.

En los diez años del primer peronismo, cada 17 de octubre habrá de reiterarse la convocatoria a la Plaza de Mayo como forma de recrear el mito de los orígenes, 
reforzando así el rostro plebeyo de esa identidad política peronista en construcción y el aspecto más plebiscitario de su legitimidad. Así, cada 17 de octubre Perón volvía a recrear la magia de su vínculo con el pueblo en un acto que le renovaba la legitimidad de origen. En esos diez años, la Plaza de Mayo porteña repetía escenarios festivos en distintas fechas, cada una de ellas con importante carga simbólica, pero los 17 de octubre estaban reservados a la identidad peronista. Si el 25 de mayo o el 9 de julio el peronismo invocaba a la Nación, o el $1^{\circ}$ de mayo a la clase obrera, el 17 de octubre se invocaba a sí mismo: ese era el día peronista por excelencia, cuando el peronismo volvía a poner en escena los acontecimientos que en 1945 le habían dado su lugar en la historia.

Luego de la caída de Perón en 1955 la fecha tendría un natural cambio en el calendario simbólico peronista sin perder su sitial de privilegio. Por un lado, sin el control del Estado y con las limitaciones impuestas por la proscripción en los años posteriores al 55, la movilización del peronismo se reorientará, alejándose de la plaza y de la fastuosidad de la convocatoria masiva, para ganar radicalidad en la protesta social que acompańa toda la etapa de lo que se conoce como «la resistencia».

La masividad de los ańos dorados del primer peronismo y la radicalidad de los ańos de la resistencia habrán de coincidir por breve tiempo luego del retorno de Perón al país y al Estado en 1973, para demostrar rápidamente cuánto había de irreconciliable en esas dos tradiciones que el peronismo había incubado. La dureza del enfrentamiento de esos años inmediatos anteriores a la última dictadura militar, tal vez ayude a explicar el lugar más acotado que el 17 de octubre ocupa desde entonces.

En las dos últimas décadas, mientras el peronismo ha demostrado con creces una renovada capacidad para mantenerse como opción de poder, el 17 de octubre se ha apagado como faro identitario. Dicho de otra manera: dejando en el camino la movilización de masas que le estaba asociada como proceso de recreación del mito originario, el 17 se ha vuelto una fecha más privada, ha perdido capacidad de intimidar políticamente. El peronismo de nuestros días puede renovar sus credenciales de sujeto de poder sin necesitar de la recreación del 17 de octubre paradigmático, el que destacaba su rasgo plebeyo ejerciendo una interpelación al poder en nombre de los sectores populares. 